\title{
3 次元アトムプローブによる半導体ナノ構造の元素分布解析
}

清水 康雄*1・井上 耕治*1.高見澤 悠*1

矢野 史子 $* 1, * 2 \cdot$ 永井 康介*1

\author{
Elemental Distribution Analysis of Semiconductor Nanostructures with \\ Atom Probe Tomography \\ Yasuo SHIMIZU*1, Koji INOUE*1, Hisashi TAKAMIZAWA*1, \\ Fumiko YANO*1,*2 and Yasuyoshi NAGAI*1
}

\begin{abstract}
*1The Oarai Center, Institute for Materials Research, Tohoku University, 2145-2 Narita-cho, Oarai-machi, Ibaraki 311-1313, Japan *2Department of Electrical and Electronic Engineering, Tokyo City University, 1-28-1 Tamazutsumi, Setagaya-ku, Tokyo 158-8557, Japan
\end{abstract}

(Received April 9, 2013, Accepted June 6, 2013)

\begin{abstract}
Atom probe tomography (APT) is a powerful characterization method to obtain three-dimensional (3D) distributions of atoms in materials at nearly atomic-scale resolution by detecting atoms one by one, which are field-evaporated from the apex of needle-shaped specimen. Recent laser-assisted APT system allows analysis of not only metals (conductive materials) but also semiconducting and insulating materials. Advanced sample preparation using focused ion beam apparatus equipped with high resolution scanning electron microscope contributes to site-specific analysis in semiconductor-based nanodevice structures. Such an innovative methodology to visualize elements in 3D has enabled application of APT in the broad area of materials science and engineering. In this article, we focus on recent studies using APT; dopant distribution analysis in modern metal-oxide-semiconductor and fin-type field-effect transistors, ion-implanted deuterium analysis in silicon, and intrinsic spatial resolution evaluation of APT using silicon isotopic multilayers.
\end{abstract}

\section{1. はじめに}

3 次元アトムプローブ (Atom Probe Tomography: APT) 法は，原子レベルに近い空間分解能で，試料を構成する元素 の 3 次元実空間分布を得ることのできる分析手法であ る1-3)．針状に加工した試料に高電圧を印加することによっ て先端の原子をイオン化・電界蒸発させ，そのイオンを位置 敏感検出器で捉え, 元素の 3 次元マッピングを構築するも のである. 従来の APT 法はパルス電圧を用いて電界蒸発を 誘起することから, 原理的に観察対象が高導電性材料に限ら れていた. 近年, パルス電圧の代わりにパルスレーザーを試 料先端に照射して電界蒸発を補助するレーザーAPT 法が開 発されたことで, 半導体・絶縁体材料への適用が可能とな り, 半導体材料からデバイスに渡る広範囲な研究が盛んに実 施されるようになった ${ }^{4-8)}$.

最近の APT 法の適用範囲の広がりは，パルスレーザー補 助以外に, 微細加工技術の進歩による寄与も非常に大き (9). 従来, 針状試料の作製には電解研磨による加工法が一 般的であったが, 最近では, 高分解能な走査電子顕微鏡 (Scanning Electron Microscope: SEM) を備えた集束イオン ビーム (Focused Ion Beam: FIB) 装置を用いることで特定 の領域を狙った針状試料の加工が効率良く行えるようになっ た。例えば，シリコン $(\mathrm{Si})$ 系の金属一酸化物ー半導体 (Metal-Oxide-Semiconductor: MOS) 型デバイスの特性に多

*1 東北大学金属材料研究所（干 $311-1313$ 茨城県東茨城郡大洗町 成田町2145-2)

*2 東京都市大学工学部電気電子工学科（干158-8557 東京都世田 谷区玉堤 1-28-1)
大な影響を与える多結晶 $\mathrm{Si}$ ゲートや多結晶 $\mathrm{Si}$ / 酸化膜界面 といった特定部位をSEM で観察しながら，それらを針試料 先端に含む加工が可能になった.

本稿では, まず APT 法の原理を解説した後, 応用例とし て半導体デバイス構造への適用事例10,11), 次世代デバイスと して注目されている $\mathrm{Si}$ 系 finトランジスタ構造中のドーパ ント分布評価について解説する ${ }^{12)}$. また, 分析チャンバー 内の水素と区別するべく $\mathrm{Si}$ 中にイオン注入した重水素の挙 動13), APT 法の定量的な空間分解能評価の方法として半導 体同位体超構造を用いた評価例を紹介する ${ }^{14)}$.

\section{3 次元アトムプローブ法の測定原理}

APT 法（Fig. 1）では試料表面に高電場を加えるために 針状の試料を用いる. 一般に, 先端半径 $r$ 針状試料に電圧 $V$ を加えると, 針試料表面での電場 $F$ は， $V / k r$ で表わされ る（ $k(2 \sim 5$ 程度）は試料 (形状 ·材質) に依存する定数). 実際の測定では先端半径が数 $10 \sim 100 \mathrm{~nm}$ の針状試料に $\mathrm{kV}$ オーダーの電圧を印加することで, 試料表面に $10 \sim 100 \mathrm{~V} /$ $\mathrm{nm}$ という非常に高い電場が生じ, 針先端の原子がイオン化 して電界蒸発を起こす. 3 次元情報を得るためには, まずイ オン化原子を位置敏感検出器で収集し, 針試料の長手方向に 対して垂直な方向 ( $\mathrm{X}-\mathrm{Y}$ 方向) の情報を取得する. $\mathrm{X}-\mathrm{Y}$ 方 向で原子レベルのマッピングができる理由は, 金属の場合は 試料表面近傍の電場によって, イオン化後の飛行方向が試料 表面に対して垂直方向であるためである. 電界蒸発は針先端 の最表層から順に起こることから, そのイオンを連続的に収 集することで針の長手方向（Z方向）のデータを蓄積する. 実際の測定では試料表面での原子の拡散を抑制するため, 通 常 $20 \sim 70 \mathrm{~K}$ 程度に冷却して行い, $\mathrm{Z}$ 方向に約 $0.2 \mathrm{~nm}, \mathrm{X}-\mathrm{Y}$ 方向に約 $0.5 \mathrm{~nm}$ 程度の空間分解能が実現可能である. 元素 


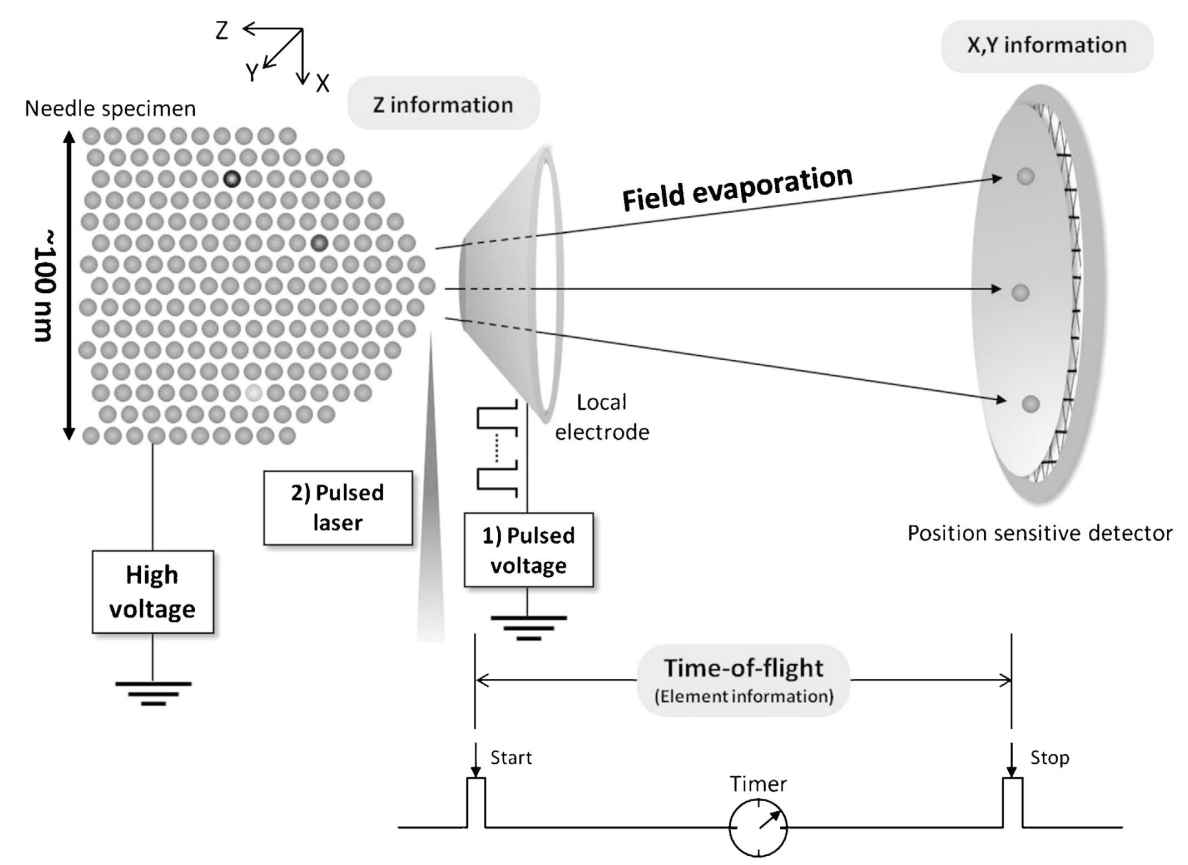

Fig. 1 Schematic illustration of APT. 1) Pulsed voltage or 2) pulsed laser is used to generate field evaporation.

(a)

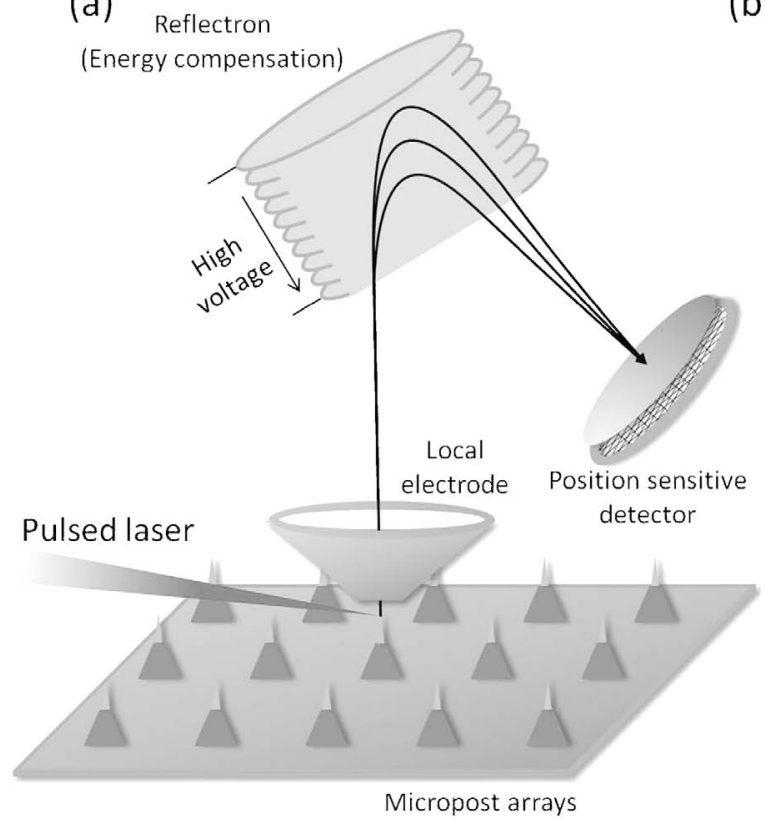

(b)

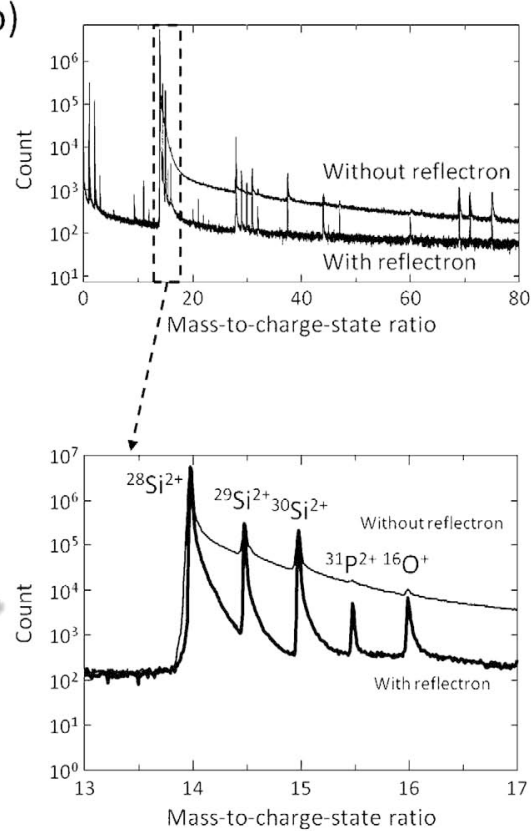

Fig. 2 (a) APT system equipped with a reflectron for energy compensation. (b) Typical APT mass spectra of Si substrates with and without a reflectron.

はイオンが電界蒸発後に加速されて位置敏感検出器に到達す るまでの飛行時間による質量分析を用いて特定するＡPT 法は他の手法と異なり，イオン検出効率が元素の種類にほと んぞ依存しない点が特長である.

従来型の APT 法では, 電界蒸発を定常電圧（電界蒸発が 発生するしきい值未満に制御した電圧）にパルス電圧を重ね 合わせることで引き起こす。このパルス電圧を用いた方法で は, 低導電性の半導体や絶縁体材料に対して, 針状試料の先 端が瞬間的には等電位面にならず電界蒸発の制御が困難であ ったが，パルス電圧をパルスレーザー（ピコ秒またはフェム
ト秒）に置き換えたレーザー補助型の APT を利用すること によって，これらの材料分析が可能となったレレーザーによ る電界蒸発の主な補助機構は, 主として針状試料の先端の温 度が瞬間的に上昇し，熱励起によって電界蒸発を補助する仕 組みであると考えられているが15,16)，レーザーによる電子励 起17)や電界変調18 による影響など様々な機構が寄与してい ると考えられている。本稿で示す分析事例は緑色レーザー （波長：532 nm）を用いたものであるが，電界蒸発のレー ザー波長依存性が報告されて抢り，短波長側の紫外光レー ザーを用いることで，絶縁体材料の測定がより容易にな 
(a)

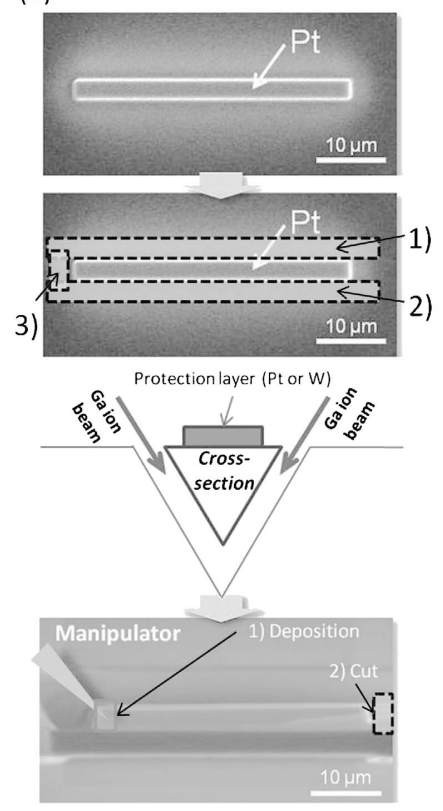

(b)
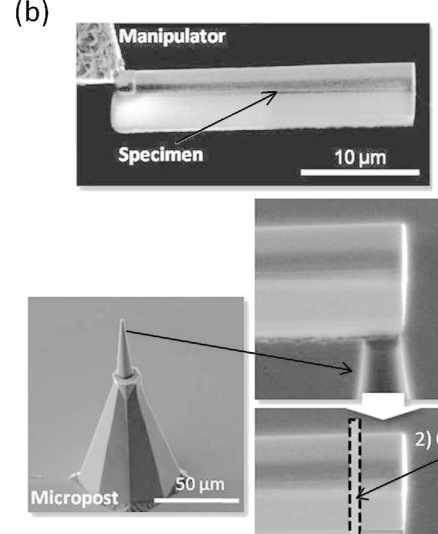

(c)

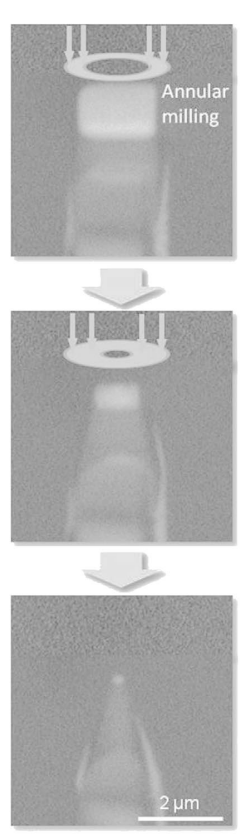

Fig. 3 Needle-shaped specimen preparation for APT. (a) Lift-out method, (b) mounting on Si microposts, and (c) needle fabrication using annular milling patterns.

$ろ^{19,20)}$.

今回使用した APT 装置は, 局所電極21,22）（Fig. 1）を試 料近傍に装備したタイプである. 局所電極の主な利点は, (1) 比較的低い電圧で針状試料先端に高電場を生じさせることが できるため, 測定中の試料破壊頻度を激減できる点, (2)局所 電極の近傍のみに高電場が生じるため, 特定の針試料の久の 測定が可能となり, Fig. 2(a)に示す通り，一度に多数の針 状試料を分析チャンバー内に導入し, 試料交換時間を大幅に 短縮できる点, (3)イオン化させるための電圧とイオンを検出 器に到達させるための電圧を分離でき, 飛行中のイオンの持 つ運動エネルギーのばらつきを軽減できるため, 試料一検出 器間の距離を短くしても質量分解能を保たれ，従来に比べ蒸 発した原子を広角で検出し，大面積（約 $100 \mathrm{~nm} \times 100 \mathrm{~nm}$ ） のデータが得られる点, など多数ある.

さらに, リフレクトロンと呼ばれるエネルギー補償装置に よって, 電界蒸発時の運動エネルギーのばらつきを相殺する ことができ, 質量分解能が向上する。これにより, $\mathrm{Si}$ 系 MOS デバイスにとって重要なドーパント種であるリンと母 体 $\mathrm{Si}$ との識別が容易になり, $\mathrm{Si}$ 結晶密度 $\left(5 \times 10^{22} \mathrm{~cm}^{-3}\right)$ に対して $10^{18} \mathrm{~cm}^{-3}$ オーダーの微量ドーパントを検出できる ようになった. Fig. 2(b)に Si 材料の典型的な質量スペクト ルを示す.この図の通り, 電界蒸発したイオンの質量分解能 の向上とバックグラウンドの低減が図れている．質量分析の 面では, 二次イオン質量分析 (Secondary Ion Mass Spectrometry： SIMS）法と比較されることが多いが，APT 法は本 質的にサブナノメートルオーダーの分解能で 3 次元の元素 情報を得られる点が最大の特色である. 但し, リフレクトロ ン内部の構造物により飛行したイオンが散乱され，イオンの 検出効率の僅かに減少するデメリットがある.

\section{3. 集束イオンビームを用いた針状加工技術}

針状試料の加工は, APT 評価の成否を決める最も重要な 技術の一つである. 従来, バルク金属材料では電解研磨によ って針状加工するのが一般的であったのに対し，半導体デバ イスでは特定部位の精密加工が必要であるため, SEM 観察 しながら FIB を用いて針加工を実施する. 最近, 高分解能 SEM 観察が行えるようになったことで, 所望の特定部位を 針状試料の測定に最適な深さに加工することが可能となっ た . $^{9}$.

一例として Fig. 3 に APT 用試料の一連の加工手順を示 す。まず, FIB 装置に備わっている白金 $(\mathrm{Pt})$ やタングス テン（W）なぞで所望の部位を含むように試料表面に保護 膜を形成する. 斜め方向からガリウム $(\mathrm{Ga})$ イオンを照射 して保護膜周辺部を削る. そして, マニピュレータの先端に デポシシション機能により試料を接着させ, 試料片を持ち上げ る (Fig. 3(a)). 続いて, この試料片をSi マイクロチップ (本研究では, 高さ約 $100 \mu \mathrm{m}$, トップ平坦部約 $2 \mu \mathrm{m}$ 径のマ イクロポストが複数配列された $\mathrm{Si}$ チップを使用 : Fig. 2(a) の模式図参照）上のマイクロポストのトップ平坦部に位置調 整して接合する. 試料を切り離すために Ga イオン照射し, 試料をマイクロポストにマウントする (Fig. 3(b)). マウン トされた試料は, 上方から環状パターンにGaイオンを照射 することで円錐状に加工する. 環状パターンの内径を徐々に 狭めることで試料先端部を先鋭化する (Fig. 3 (c)). 最終的 に, SEM で確認しながら観察対象領域が針状試料の先端か ら50 100 nm 程度内に含まれるように深さを調節して試料 を仕上げる.

以上のように, FIB の加工技術の発展があって初めて半 導体デバイス構造の APT 評価が可能となった。 


\section{4. 半導体材料/デバイス構造への適用例}

\section{1 $\mathrm{Si}$ 系 MOS 構造試料への適用例}

本章では，半導体材料やデバイス構造への適用例を示す。 まず，MOS デバイス構造（Fig. 4(a)）に針加工を施し，

Fig. 4(b)の透過電子顕微鏡（Transmission Electron Microscope: TEM) 像の通り, 針状試料の中に含むようにする. すると，Fig. 4(c)，4(d)のようにAPT 法でドーパントの評 価が可能である10,11)．点 1 個が原子 1 個に対応する．多結晶 ゲート, ゲート酸化膜, チャネル, ソース・ドレイン領域を 含む MOS トランジスタ構造の構成元素の 3 次元実空間分布 が明瞭に観察されている。APT法では，検出した原子に対 して本質的に 3 次元の情報が得られるため，目的によって 最適な方向からの断面や投影像など選択し，元素分布につい

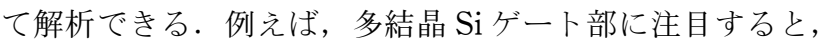

Fig. 5 (a) には $\mathrm{n}$ 型 MOS 中の元素分布を示すが，水平方向 の断面像からリンの明らかな粒界・界面偏析が観察できる.

一方, p 型 MOS 中のホウ素（Fig. 5 (b)）では，明らかな 粒界偏析は見られない。このような定性的な情報のみなら ず，粒界・粒内の元素濃度までも APT 法を用いれば定量的 に求めることができる．最近では MOS デバイスの電気的特 性とチャネルドーパント分布を直接対応させることによっ て，微細化の問題である素子特性ばらつきの原因を解析する 応用例 23$)$ もり，市販品の MOS トランジスタの評価にも適 用できる ${ }^{24-27)}$. MOS デバイスの研究の詳細は, 過去の解説 記事 ${ }^{28)}$ に譲ることにする.

\section{$4.2 \mathrm{Si}$ 系 fin 構造中の 3 次元ドーパント分布観察}

$\mathrm{Si}$ 系デバイス構造は, 性能の更なる向上に向け平面から

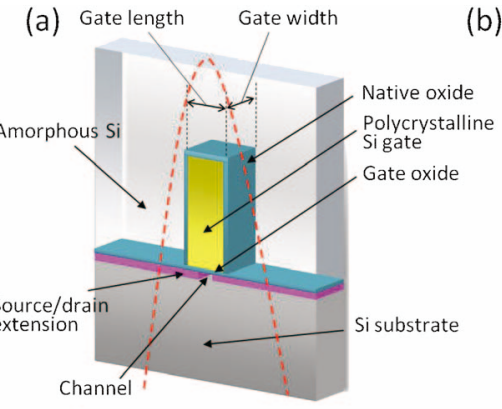

(b)

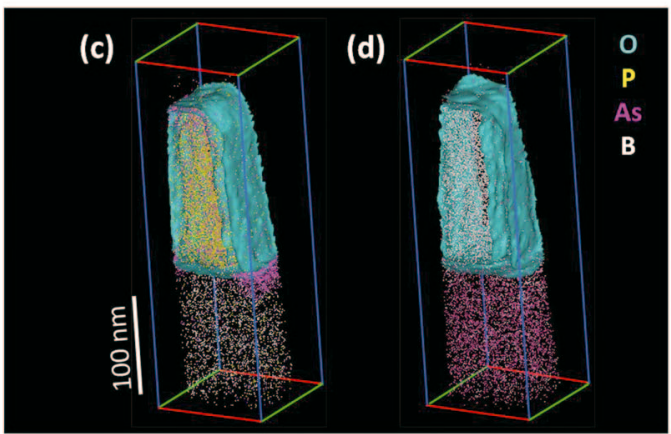

Fig. 4 (a) Schematic illustration of MOS device structure analyzed by APT. The red broken curve indicates the needle position of APT. (b) Cross-sectional TEM image of the device structure. (c) and (d) exhibit elemental maps ( $O$ isoconcentration at 3 at $\%, \mathrm{P}, \mathrm{As}, \mathrm{B})$ of n-type and p-type MOS device structures, respectively.
立体構造へシフトし, より複雑化している ${ }^{29)}$. 今後は立体 構造（例えば，finトランジスタ）中のドーパント分布を知 ることは極めて重要である，APT 法は，このような複雑な 構造に対して適用可能である.

新規デバイス開発においては，プロセス途中で試料（ウ土 八）を抜き取り，それを解析し，結果をプロセス改良にフ ィードバックすることで効率化を図っている，その場合，例 えば，被観察領域が表面に露出している試料を評価しなけれ ばならない，そのため，針状試料内部の適切な位置に対象領 域が含まれるよう, 表面を埋めなければならない。埋め込み 膜材料の候補としては，APT 用の FIB 加工時に，ミリング 速度が埋め込み膜と試料間で大きく変化しないこと, 且つ電 界蒸発のしきい值も変化しないことが望ましいことから，試 料と同じ材料（本研究では Si）が最適である.

今回, プロセス途中段階の fin トランジスタ評価 (Fig. 6 (a)，6(b)）に向けて，Si 埋め込久膜を形成すべきだが，室

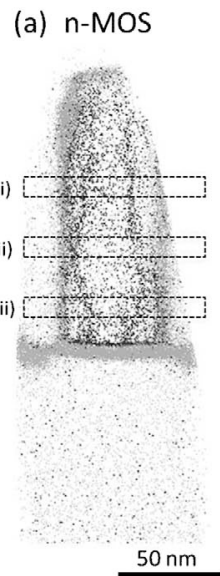

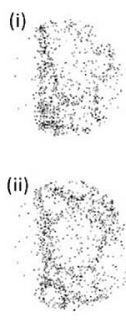

(iii)

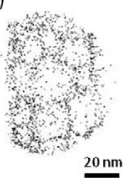

(b) p-MOS

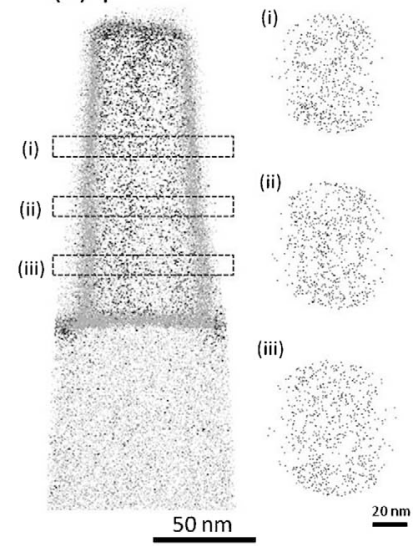

Fig. 5 Projected atom maps (O, P, As, B) of $20 \mathrm{~nm}$ thick slices of (a) n-type and (b) p-type MOS device structures. Projected atom maps ( (a) P and (b) B) of $10 \mathrm{~nm}$ thick slices of polycrystalline-Si gate are shown in (i), (ii), and (iii).
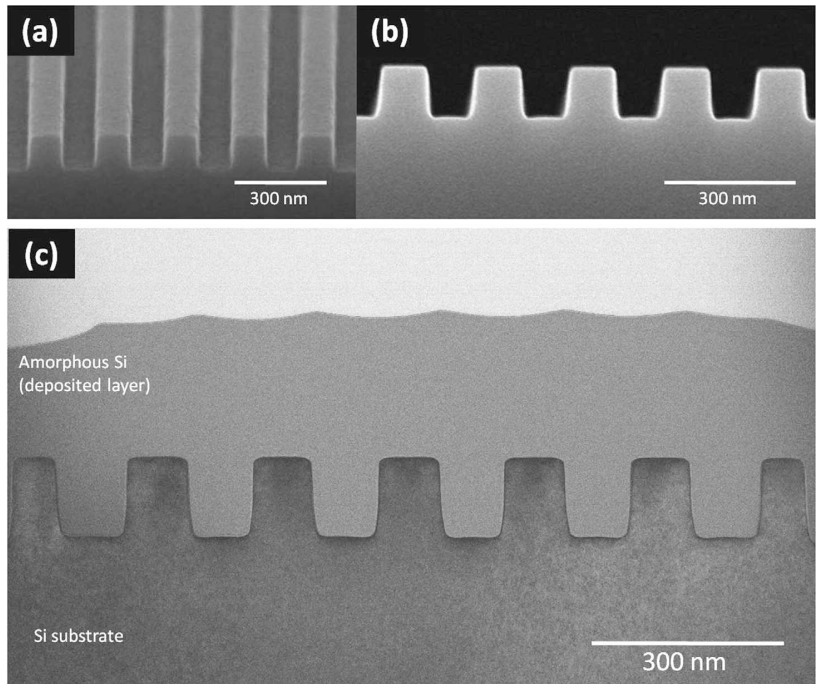

Fig. 6 (a) SEM image of uncovered Si fin arrays. (b) The side view. (c) Cross-sectional STEM images after filled with a-Si on fin arrays. 
温で被覆性・接着性に優れた $\mathrm{Si}$ の成膜は容易ではない。例 えば, 通常のスパッタ蒸着法では, 溝部の角に隙間ができて しまう。また，化学気相法による成膜では，温度上昇による 試料状態の变化や空隙の形成等の問題が懸念されていた.こ

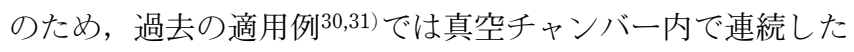
プロセスで埋められたものであった.

この問題を解決するために, 集束イオンビーム直接蒸着 (Focused Ion Beam Direct Deposition: FIBDD) 法32) という 手法で $\mathrm{Si}$ の低エネルギービーム $(\sim 200 \mathrm{eV})$ を当てること で Si 膜を形成した. 低エネルギーのビームにより極力損傷 を抑えられ, 室温で空隙無く被覆性・接着性の高い膜を形成 できるようになった. Fig. 6 (c) に FIBDD 法で埋め込み膜 を形成した試料の断面走查透過電子顕微鏡（Scanning Transmission Electron Microscope: STEM) 像を示す. fin
と埋め込みアモルファス $\mathrm{Si}(\mathrm{a}-\mathrm{Si})$ 膜の界面に空隙がないこ とが分かる。

ここでの対象試料 (Fig. 6(a)) は, 自己調節プラズマドー ピング (Self-Regulatory Plasma Doping: SRPD) 法33)によ って fin 配列全体の極表面にホウ素を添加したものである. まず, Fig. 7 (a)にAPT 法で得られた元素マップ $\left({ }^{28} \mathrm{Si}\right.$, $\left.{ }^{30} \mathrm{Si}, \mathrm{B}, \mathrm{O}\right)$ を示す. このように APT 測定に成功できたのは, FIBDD 法による被覆性・接着性の優れた膜形成のおかげで ある.これにより fin 最表面でのホウ素分布を 3 次元的に評 価できるようになった. Fig. 7 (b)に fin 上部に抢ける ${ }^{30} \mathrm{Si}$ 分布を示すＦIBDD 法では，この試料では埋め达久膜とし て高純度な ${ }^{28} \mathrm{Si}$ を利用しているため, ${ }^{30} \mathrm{Si}$ を指標とすること で試料本体と明確に区別でき， ${ }^{30} \mathrm{Si}$ 分布の急峻性を調べるこ とで膜形成時の fin 表面への損傷がほとんど無いことが確認 (a)
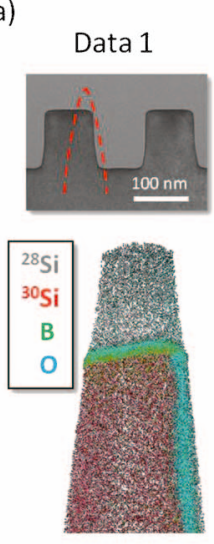
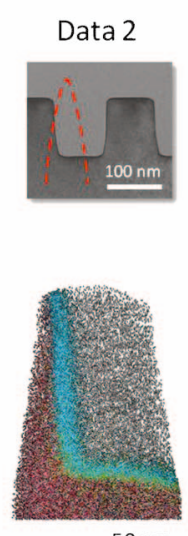

(b)

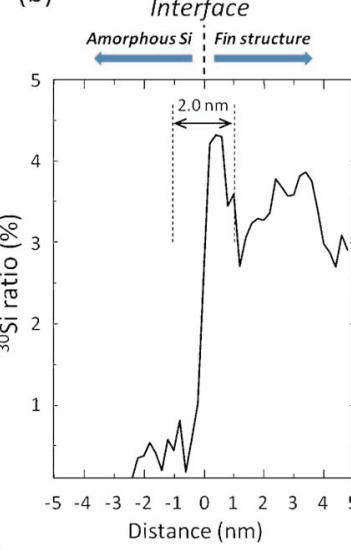

(c)

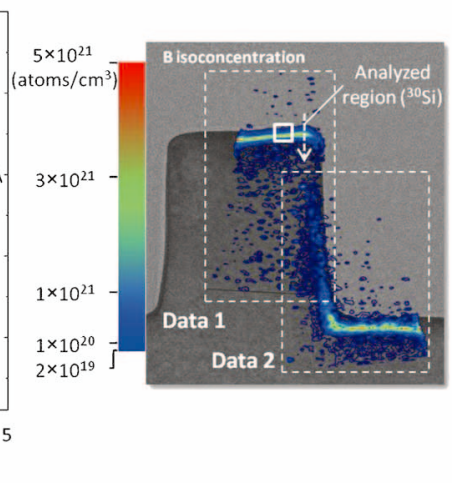

Fig. 7 (a) Observed regions are indicated by broken curves overlaid with cross-sectional STEM images of Si fin arrays. Elemental maps of specimens for two independent needle positions (Data $1 \&$ Data 2). (b) $1 \mathrm{D}$ concentration profile of ${ }^{30} \mathrm{Si}$ across the top interface. (c) Projected 2D concentration profiles of B with cross-sectional STEM image.

(a)
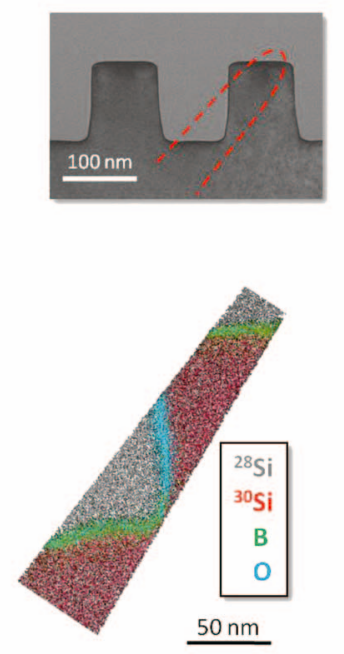

(b)

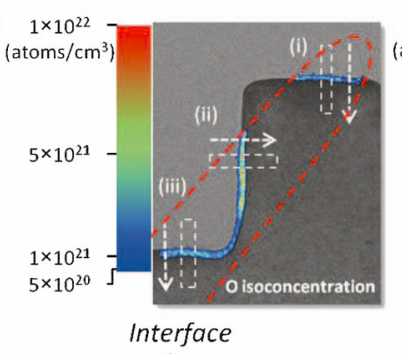

(c)
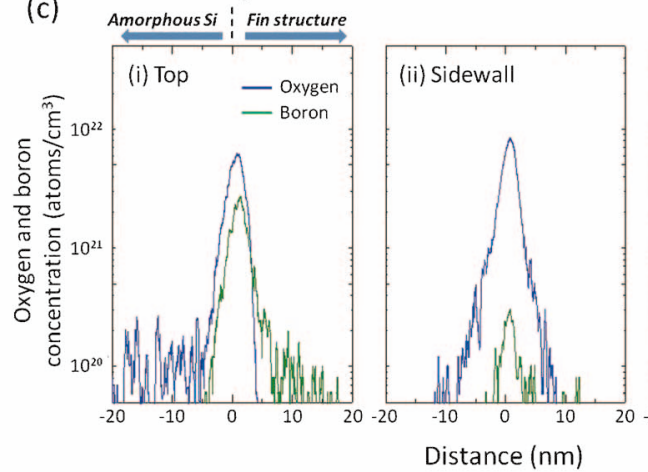

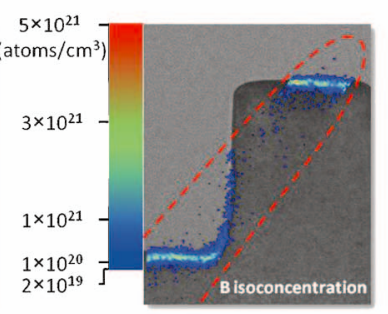

$2 \times 10^{19}$

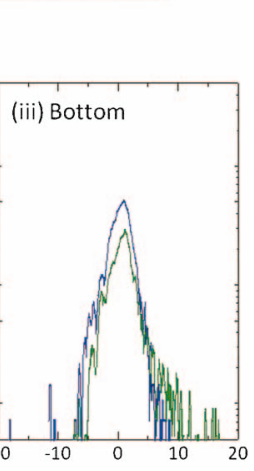

Fig. 8 (a) Observed region in APT is indicated by a broken curve on the cross-sectional STEM image of Si fin arrays and elemental map of a specimen tilted at $\sim 45^{\circ}$. (b) Projected $2 \mathrm{D}$ concentration profiles of $\mathrm{O}$ and $\mathrm{B}$ with cross-sectional STEM images. (c) $1 \mathrm{D}$ concentration profiles of these elements across (i) top, (ii) sidewall, and (iii) bottom interfaces. 
できる.

今回用いた fin 配列のサイズでは，1つの針状試料に fin 上面，側壁面，底面をすべて収めることができず，異なる 2 箇所の位置で針状加工を行った．これらのデータ（Data $1 \&$ Data 2) のホウ素の 2 次元濃度分布を断面 STEM 像に重ね 合わせたものを Fig. 7 (c) に示す. Data $1 \&$ Data 2 ともに側 壁面に拈いては，ホウ素の濃度低下があることが分かった.

ホウ素分布の広がりや濃度をより定量的に求めるために, $45^{\circ}$ 万向から針状試料を用意した。これは，第 2 章にて述べ たが，APT 法の空間分解能は原理的に横方向 (X-Y 方向) と深さ方向（Z方向）で異なるためであり，この方向からの 加工により, fin 上面・側壁面 ·底面に直交する方向に対し て同程度の空間分解能を満たすことができる. Fig. 8(a)に 元素マップを示す.このように針状加工の方向を変えても, 問題なくAPT 測定できている. Fig. 8(b) に奥行き $20 \mathrm{~nm}$ の酸素とホウ素の 2 次元濃度分布と断面 STEM 像の重ね合 わせを示す. ホウ素は上面・側壁面·底面において, それぞ れ $2.6 \times 10^{21}, 3.0 \times 10^{20}, 2.9 \times 10^{21}$ atoms $/ \mathrm{cm}^{3}$ のピーク濃度 が得られた (Fig. 8 (c)) . 側壁面では, 上面・底面に比べ て, ドーピング濃度は約 1 桁低いが, 現在開発中の SRPD 法では少なくとも $3.0 \times 10^{20}$ atoms $/ \mathrm{cm}^{3}$ に達していることを APT 法で実証することができた.

このように, プロセス途中段階で抜き取っても FIBDD 法 による埋め込久膜形成を行うことで, APT 法で評価できる ことを実証した。

\section{$4.3 \mathrm{Si}$ 中の重水素挙動の解明}

材料中の水素の検出や定量的評価は難しいが, 真空を扱う 研究者にとって解決すべきテーマである. 半導体デバイスに 扔いても, 水素は酸化膜界面や欠陥によるダングリングボン ドを終端することによって界面準位を安定化させたり，バル ク内でキャリアを不活性化させたりできるため, 水素の挙動 を知ることは極めて重要な課題である. デバイス特性や界面 の性質に大きく影響するため, その 3 次元的な分布を定量 的に把握すべきである.

APT 法では飛行時間型の質量分析によって元素を特定す るため, 原理的には水素の検出及び定量は可能である. しか し, APT法に拈いても, 検出された水素が分析チャンバー 内の残留水素ガスであるか, 試料由来の水素であるか明確に 区別できない，水素評価の可能性を検討するために，水素の 安定同位体である重水素（D）に着目し，これをイオン注入 した Si 試料を用意し APT 観察することで, 分析チャン バー内残留ガス（真空度 : $2.7 \times 10^{-9} \mathrm{~Pa}$ ) と区別することを 試みた。

Fig. 9(a), 9(b) に重水素をイオン注入 $\left(\mathrm{D}_{2}^{+}, 10 \mathrm{keV}, 1 \times\right.$ $10^{16} \mathrm{D} / \mathrm{cm}^{2}$ ) した Si と, 通常の $\mathrm{Si}$ の APT 法で得られる典 型的な質量スペクトルを示す. 重水素をイオン注入した試料 では, Si 中の質量数/電荷 (Mass-to-Charge-State Ratio: m/ z）が $0 \sim 3$ の軽元素位置に着目すると，2のピークが高くな っていることが分かる. また, $\mathrm{m} / \mathrm{z}$ が26〜34の領域に着目 すると, 天然 $\mathrm{Si}$ の安定同位体比率 ${ }^{28} \mathrm{Si}: 92.2 \%,{ }^{29} \mathrm{Si}: 4.7 \%$, ${ }^{30} \mathrm{Si}: 3.1 \%$ ) と一致, 且つ質量数が大きい側に 2 シフトした $\mathrm{m} / \mathrm{z}$ が30, 31, 32のピークが観察された。これらのピークか
ら, 重水素及び重水素と $\mathrm{Si}$ との複合体 $(\mathrm{SiD})$ の 3 次元分 布を得ることができる. Fig. 9(c) に元素 $(\mathrm{H}, \mathrm{D}, \mathrm{SiD})$ 分布 を奥行き方向 $20 \mathrm{~nm}$ で投影した図を示す．水素は分析チャン バー内の残留ガスに依存する成分であり，位置が深くなるに つれて水素が増大する傾向にあることが分かった．これは， 測定時間とともに先端径が増大し, 電界蒸発するまでに真空 チャンバー中の表面に曝されている時間が長くなり, より多 くの水素が吸着するためであると考えられる. 一方で, D や $\mathrm{SiD}$ は試料表面から浅い領域で高濃度に分布しているこ とから, チャンバー内の残留ガスと区別して分析できている ことが明瞭である. また, D 及び $\mathrm{SiD}$ は浅い領域で凝集体 を形成していることも明らかとなった。

Fig. 10 (a)には, 重水素イオン注入した Si の断面 TEM 像を示す. Fig. 10(b)には, 3 次元分布の中で特定の大きさ の凝集体を抽出した分布を示すが，TEM で得られた欠陥分 布の形状と良く一致していることが分かる $($ Fig. $10(\mathbf{c}))$.

(a)

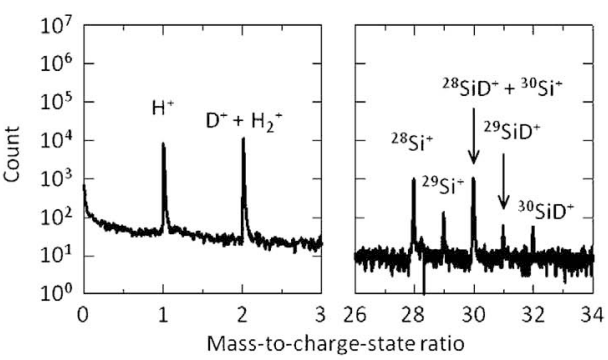

(b)

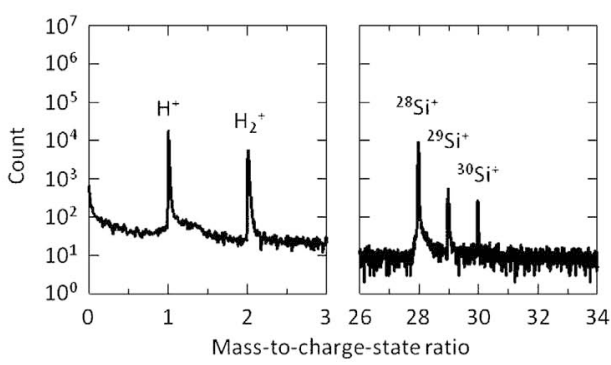

(c)
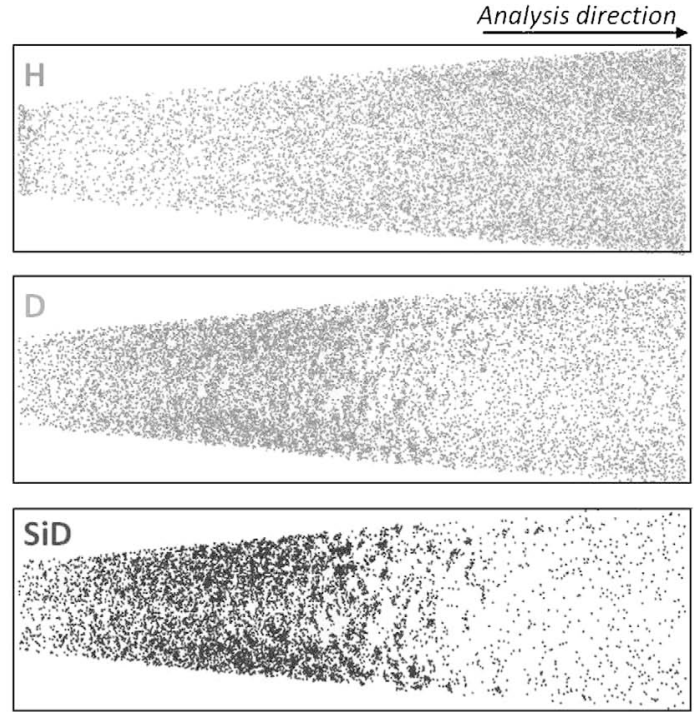

$50 \mathrm{~nm}$

Fig. 9 APT mass spectra of Si substrates implanted (a) with and (b) without deuterium. (c) Elemental maps of H, D, and $\mathrm{SiD}$ in deuterium-implanted Si. $\mathrm{D}_{2}^{+}$implantation and APT analysis direction are from left to right. 
Protection layer :

(a)

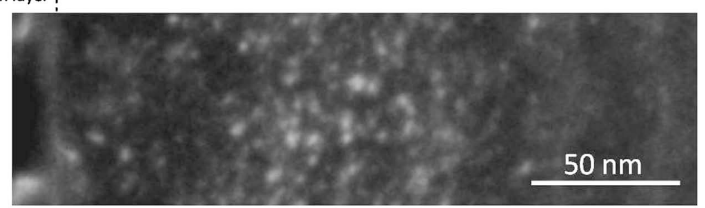

(b)

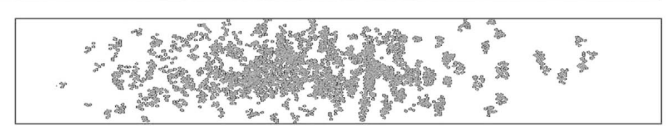

(c)

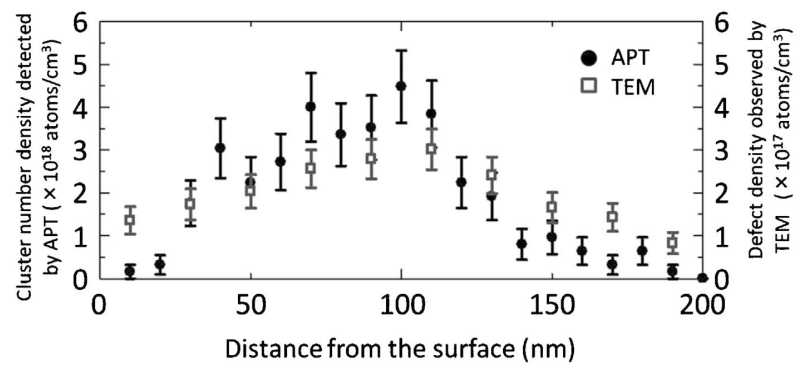

Fig. 10 (a) Cross-sectional TEM image of D-implanted $\mathrm{Si}$ substrate obtained by weak beam dark field condition. (b) D atoms distribution determined by cluster analysis $\left(d_{\max }: 1.2\right.$ $\mathrm{nm}, N_{\text {atom: }}: 10$ ). (c) Cluster density distributions obtained by APT (left axis) and defect density distribution observed by TEM (right axis).

つまり，イオン注入で生成された欠陥と重水素の分布に強い 相関があることが示唆される。但し, APT 法による凝集体 の数密度は, TEM で見られる欠陥密度に比べて約 1 桁高 い。これは, APT 法では TEM で観察が困難な微細な欠陥 にも重水素の凝集体が存在することを示唆する.

このように, 重水素イオン注入した試料中の重水素の分布 を詳しく解析することによって, 真空の分析チャンバーの水 素と区別した情報を得られることを示した. 欠陷や界面近傍 に重水素をトラップさせることで, それらの 3 次元分布観 察への応用が期待できる.

\section{4 同位体超構造を用いた 3 次元アトムプローブ法の空 間分解能評価}

第 2 章にて, 針状試料に対して長手方向とそれに直交する 方向では空間分解能が異なることを述べた．これらの方向で の空間分解能を揃えるため, 第4 章 (4.2) では, fin デバイ スを $45^{\circ}$ 方向から APT 評価を試みた。では, 実際にどの程 度異なるのか？APT 法による 3 次元分布を提示する上で, APT の高い空間分解能を保証するデータの裏付けは必須で ある.

この定量的評価を実施する場合, 異なる元素で構成される 積層面に対して針状試料の長手方向を垂直 ·平行に加工して APT 法を適用し，それぞれの方向での積層界面の急峻性を 比較すれば良い，但し，通常の多層膜構造に扔いては元素の 種類によって電界蒸発のしきい值が異なるため, 元素マッピ ング像に歪みが生じてしまう ${ }^{34)}$ 。ここでは，本質的な分解 能を調べるために同位体に着目し，原子レベルの平坦性を持 った同位体積層試料を用いることで，像の歪みの影響を減ら し, 本質的な空間分解能を比較した. 天然 $\mathrm{Si}$ には 3 種類の 安定同位体が一定の比率で存在して抢り, APT 法の質量分 析としては十分に区別できる。ここでは，分子線エピタキ (a)
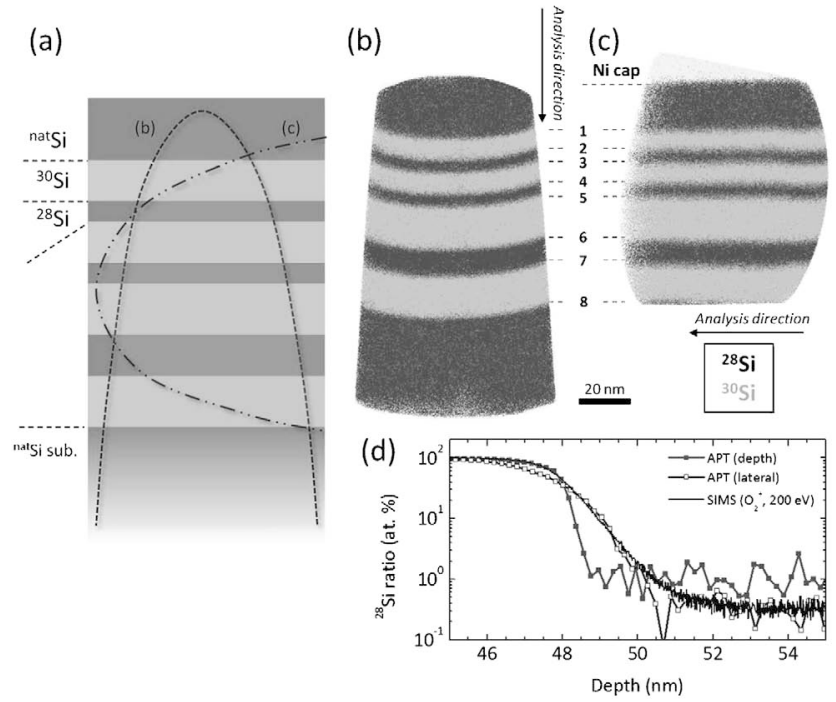

Fig. 11 (a) Schematic illustration of Si isotopic multilayer sample. $3 \mathrm{D}$ reconstruction images of ${ }^{28} \mathrm{Si}$ and ${ }^{30} \mathrm{Si}$ in $\mathrm{Si}$ isotopic multilayers oriented (b) perpendicular and (c) parallel to the needle's long axis. (d) ${ }^{28} \mathrm{Si}$ depth profiles obtained by APT and SIMS $\left(\mathrm{O}_{2}^{+}, 200 \mathrm{eV}\right)$ around the 5 th interface.

シー法を用いて原子層単位の平坦性で異なる同位体 $\mathrm{Si}$ ${ }^{28} \mathrm{Si},{ }^{30} \mathrm{Si}$ ) を周期的に積層した試料（ $\mathrm{Si}$ 同位体超構造，

Fig. 11(a)）を用意した ${ }^{35)}$.

Fig. 11 (b) に Si 同位体超構造の積層面に対して垂直方向 に針状試料作製した場合の ${ }^{28} \mathrm{Si}$ と ${ }^{30} \mathrm{Si}$ の分布を表示する. このように，質量数の近い ${ }^{28} \mathrm{Si}$ と ${ }^{30} \mathrm{Si}$ を明瞭に分離できて いる. 一方, Fig. 11(c)は, 同様に積層面に対して平行な方 向に針試料作製した場合の結果である. Fig. 11(d)には, 試料表面側加 5 番目の同位体層界面近傍にお打る ${ }^{28} \mathrm{Si}$ の 1 次元濃度分布 $(\mathrm{APT}$ 及び低エネルギーSIMS 評価) を示す。 この急峻性の比較から, 積層面に対して平行方向の APT 法 と SIMS 法ではほぼ同等であるのに対し, 垂直方向のAPT 分析では非常に高い急峻性（約 $0.4 \mathrm{~nm} /$ decade）を持つこと が分かった。

\section{5. まとめ及び今度の展望}

レーザーAPT 法の開発が進むことで, 測定対象が従来の 高導電性材料の久という制約がなくなり，半導体や絶縁体を 含む系への適用が可能となった。 その結果，半導体分野に㧈 いては基礎的な研究対象から実デバイスまで評価が可能とな った．また，半導体デバイスの APT 評価には，狙った箇所 を最適な位置・針形状に加工する FIB 技術の著しい進歩に よるところも大きく，この技術発展により，次世代の立体的 でより複雑な構造を持つデバイスの評価も可能になった．本 稿で紹介した事例以外にも, 量子細線（ナノワイヤ）尚）や量 子ドット37)などの新しいデバイス構造の評価結果も報告さ れている. デバイスの材料面に捛いては, 現在はシリコン系 のみならず，高機能化が可能な材料として注目されているゲ ルマニウム系や化合物系（III-V族）半導体など様々な応用 が進められている. 最近では, 歯38,39)のような生体材料に対 しても適用できることが報告されている，本技術は，デバイ 
スのみならず材料分野においてもさらなる発展に必要不可欠 な評価技術となるであらう。

\section{謝辞}

本研究は, 岡田徳行氏, 加藤幹雄氏, 内田博氏（東芝ナ） アナリシス株式会社), 西田彰男氏（ルネサスエレクトロニ クス株式会社), 最上徹氏 (光電子融合基盤技術研究所), 森 田弘洋氏, 藪内康文氏, 小倉基次氏（パナソニック株式会 社), 板橋踊子氏, 植松真司氏, 伊藤公平氏（慶應義塾大学） との共同研究であり, 関係諸氏に深く感謝申し上げます。 ま た, 野沢康子氏, 外山健氏（東北大学金属材料研究所）のご 協力に感謝致します。本研究の一部は, NEDO より Selete に委託された MIRAI プロジェクトの一環として実施し，科 学研究費補助金（No. 21246142, 24760246, 248082）の支援 を得て実施しました。

\section{[文献}

1) G. L. Kellogg and T. T. Tsong: J. Appl. Phys., 51 (1980) 1184.

2) T. F. Kelly and M. K. Miller: Rev. Sci. Instrum., 78 (2007) 031101.

3) B. Gault, F. Vurpillot, A. Vella, M. Gilbert, A. Menand, D. Blavette and B. Deconihout: Rev. Sci. Instrum., 77 (2006) 043705.

4) D. Blavette, A. Bostel, J. M. Sarrau, B. Deconihout and A. Menand: Nature, 363 (1993) 432.

5) K. Thompson, P. L. Flaitz, P. Ronsheim, D. J. Larson and T. F. Kelly: Science, 317 (2007) 1370.

6) H. Takamizawa, K. Inoue, Y. Shimizu, T. Toyama, F. Yano, T. Tsunomura, A. Nishida, T. Mogami and Y. Nagai: Appl. Phys. Express, 4 (2011) 036601.

7) S. Jin, K. S. Jones, P. A. Ronsheim and M. Hatzistergos: J. Vac. Sci. Technol. B, 29 (2011) 061203.

8) K. Inoue, A. K. Kambham, D. Mangelinck, D. Lawrence and D. Larson: Microsc. Today, 20 (2012) 38.

9) M. K. Miller, K. F. Russell, K. Thompson, R. Alvis and D. J. Larson: Microsc. Microanal., 13 (2007) 428.

10) K. Inoue, F. Yano, A. Nishida, H. Takamizawa, T. Tsunomura, Y. Nagai and M. Hasegawa: Ultramicroscopy, 109 (2009) 1479 .

11) H. Takamizawa, Y. Shimizu, K. Inoue, T. Toyama, N. Okada, M. Kato, H. Uchida, F. Yano, A. Nishida, T. Mogami and Y. Nagai: Appl. Phys. Lett., 99 (2011) 133502.

12) H. Takamizawa, Y. Shimizu, Y. Nozawa, T. Toyama, H. Morita, Y. Yabuuchi, M. Ogura and Y. Nagai: Appl. Phys. Lett., 100 (2012) 093502.

13) H. Takamizawa, K. Hoshi, Y. Shimizu, F. Yano, K. Inoue, S. Nagata, T. Shikama and Y. Nagai: Appl. Phys. Express, 6 (2013) 066602.

14) Y. Shimizu, Y. Kawamura, M. Uematsu, M. Tomita, T. Kinno, N. Okada, M. Kato, H. Uchida, M. Takahashi, H. Ito, H. Ishikawa, Y. Ohji, H. Takamizawa, Y. Nagai and K. M. Itoh: J. Appl. Phys., 109 (2011) 036102.

15) A. Cerezo, G. D. W. Smith and P. H. Clifton: Appl. Phys. Lett., 88 (2006) 154103

16) A. Vella, F. Vurpillot, B. Gault, A. Menand and B. Deconihout:
Phys. Rev. B, 73 (2006) 165416.

17) M. Tsukada, H. Tamura, K. P. McKenna, A. L. Shluger, Y. M. Chen, T. Ohkubo and K. Hono: Ultramicroscopy, 111 (2011) 567.

18) B. Gault, F. Vurpillot, A. Bostel, A. Menand and B. Deconihout: Appl. Phys. Lett., 86 (2005) 094101.

19) K. Hono: Oyo Buturi, 79 (2010) 317.

20) K. Hono, T. Ohkubo, Y. M. Chen, M. Kodzuka, K. Oh-ishi, H. Sepehri-Amin, F. Li, T. Kinno, S. Tomiya and Y. Kanitani: Ultramicroscopy, 111 (2011) 576.

21) O. Nishikawa and M. Kimoto: Appl. Surf. Sci., 76/77 (1994) 424.

22) T. F. Kelly and D. J. Larson: Mater. Character., 44 (2000) 59.

23) H. Takamizawa, Y. Shimizu, K. Inoue, T. Toyama, F. Yano, A. Nishida, T. Mogami, N. Okada, M. Kato, H. Uchida, K. Kitamoto, T. Miyagi, J. Kato and Y. Nagai: Appl. Phys. Lett., 100 (2012) 253504.

24) K. Inoue, H. Takamizawa, K. Kitamoto, J. Kato, T. Miyagi, Y Nakagawa, N. Kawasaki, N. Sugiyama, H. Hashimoto, Y. Shimizu, T. Toyama, Y. Nagai and A. Karen: Appl. Phys. Express, 4 (2011) 116601.

25) K. Inoue, H. Takamizawa, Y. Shimizu, T. Toyama, F. Yano, A. Nishida, T. Mogami, K. Kitamoto, T. Miyagi, J. Kato, S. Akahori, N. Okada, M. Kato, H. Uchida and Y. Nagai: Appl. Phys. Express, 6 (2013) 046502.

26) D. J. Larson, D. Lawrence, W. Lefebvre, D. Olson, T. J. Prosa, D. A. Reinhard, R. M. Ulfig, P. H. Clifton, J. H. Bunton, D. Lenz, J. D. Olson, L. Renaud, I. Martin and T. F. Kelly: J. Phys.: Conf. Ser., 326 (2011) 012030.

27) F. Panciera, K. Hoummada, M. Gregoire, M. Juhel, F. Lorut, N. Bicais and D. Mangelinck: Microelectron. Eng., 107 (2013) 167.

28) K. Inoue, Y. Shimizu and H. Takamizawa: Butsuri, 67 (2012) 645.

29) International Technology Roadmap for Semiconductors: http://www.itrs.net/

30) T. Izumida, K. Okano, T. Kanemura, M. Kondo, S. Inaba, S. Itoh, N. Aoki and Y. Toyoshima: Jpn. J. Appl. Phys., 50 (2011) $04 \mathrm{DC} 15$.

31) A. K. Kambham, J. Mody, M. Gilbert, S. Koelling and W. Vandervorst: Ultramicroscopy, 111 (2011) 535.

32) S. Nagamachi, M. Ueda and J. Ishikawa: J. Vac. Sci. Technol. B, 16 (1998) 2515.

33) Y. Sasaki, K. Okashita, K. Nakamoto, T. Kitaoka, B. Mizuno and M. Ogura: Tech. Dig. Int. Electron Devices Meet., (2008) 917.

34) S. Koelling, N. Innocenti, G. Hellings, M. Gilbert, A. K. Kambham, K. De Meyer and W. Vandervorst: Ultramicroscopy, 111 (2011) 540.

35) Y. Shimizu and K. M. Itoh: Thin Solid Films, 508 (2006) 160.

36) D. E. Perea, E. R. Hemesath, E. J. Schwalbach, J. L. LenschFalk, P. W. Voorhees and L. J. Lauhon: Nature Nanotech., 4 (2009) 315.

37) A. D. Giddings, J. G. Keizer, M. Hara, G. J. Hamhuis, H. Yuasa, H. Fukuzawa and P. M. Koenraad: Phys. Rev. B, 83 (2011) 205308.

38) L. M. Gordon and D. Joester: Nature, 469 (2011) 194.

39) L. M. Gordon, L. Tran and D. Joester: ACS Nano, 6 (2012) 10667. 